\section{Unterschiede in der Zusammensetzung der Carotinoide von Actinia equina (L.) aus der Nordsee und aus der Adria}

\author{
Franz-Christian CZYGan \\ Institut für Pharmakognosie der Botanischen Anstalten \\ der Universität Würzburg und

\section{Hans Seefried} \\ Botanisches Institut der Universität Erlangen-Nürnberg \\ (Z. Naturforsch. 25 b, 761-762 [1970] ; eingegangen am 8. Mai 1970)
}

Seit langem werden morphologische und ökologische Unterschiede der verschiedenen Herkünfte von Actinia equina beschrieben und zur Aufstellung infraspezifischer Taxa verwendet ${ }^{1}$. Die Vielzahl der Übergänge zwischen einzelnen Formengruppen erschwert jedoch genaue Unterscheidungen. - Während eingehender Untersuchungen zum Stoffwechsel und zur Biochemie tierischer Carotinoide analysierten wir auch die für Experimente unter konstanten Laborbedingungen gut geeigneten Aktinien (Einzelheiten zur Kultur etc.: CZYGan u. SeEfried, in Vorbereitung). Wir verwendeten hauptsächlich Actinia equina aus der Nordsee (ca. 250 Stück; gesammelt bei Helgoland) und aus der Adria (ca. 600 Stück; gesammelt an der jugoslawischen Küste). Daneben untersuchten wir je 10 Tiere von der Küste bei Neapel und von der portugiesischen sowie französischen Atlantikküste. In allen Fällen ließen sich in den roten, braunen und braun-grünen Farbformen der verschiedenen Herkünfte Keto-Carotinoide nachweisen, die sich jedoch in ihrer Struktur charakteristisch unterschieden (zur Analyse der Pigmente ${ }^{2-4}$ ). Alle roten und rotbraunen Adria- und Neapel-Tiere enthielten als hauptsächliche Farbkomponente Actinoerythrin, das erstmals 1933 von LEDERER $^{5}$ und später von Heilbron et al. ${ }^{6}$ sowie von De Nicola und GoodWIN ${ }^{7}$ isoliert worden war. Kürzlich schlugen HERTZberg und Lianen-Jensen ${ }^{4}$ für dieses Pigment die Struktur eines Diesters des 2.2' -Bis-nor-3.3'-dioxi-4.4'dioxo- $\beta$-carotins vor. Unsere experimentellen Daten stimmen mit denen von HerTZBERg und LiAAen-JENSEN überein. Als Säurekomponenten enthielt Actinoerythrin vor allem Hexadecan-, Octadecan-, Hexadecen-, Octadecen- und Hexadecadiensäuren (WAGNER und CzYGAN, unveröffentlicht). Die in den Mittelmeertieren nur gelegentlich in Spuren vorkommenden Astaxanthinester waren dagegen die Hauptpigmente in den rötlichen, braunen und braungrünen Nordsee- und Atlantik-Proben. In diesen Herkünften fehlte Actinioerythrin völlig. Die Fähigkeit, Actinioerythrin zu bilden, ist genetisch fixiert. Jungtiere beider Formenkreise (Nordseetiere

1 F. PAX, in: Anthozoa-Rassenbildung, G. GRImpe u. E. Wagler (Herausg.), Tierwelt der Nord- und Ostsee. IIIe, 190. Leipzig 1936.

F. Pax u. I. Müller, in: Die Anthozoenfauna der Adria (Fauna et Flora Adriatica III), Split 1962.

2 P. Karrer u. E. Jucker: Carotinoide. Birkhäuser, Basel 1948.

3 F.-C. Czygan, Arch. Mikrobiol. 61, 81 [1968] ; Flora [Jena] Abt. A. 159, 339 [1968].

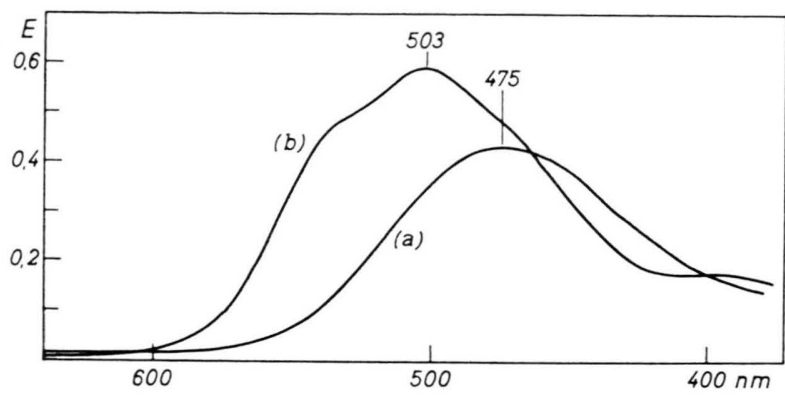

Abb. 1. Methodische Daten: Gerät Zeiss DMR 21, Vorschub: $15 \mathrm{~min}$, Wellenlängenentzerrung: $1 \mathrm{~mm} \triangleq 1 \mathrm{~nm}$, Küvetten: $1 \mathrm{~cm}$; Glas, Lösungsmittel: Aceton p.a., Substanzen: a) nativer Gesamtextrakt von Actinia equina „Nordsee“, b) nativer Gesamtextrakt von Actinia equina „Adria“.

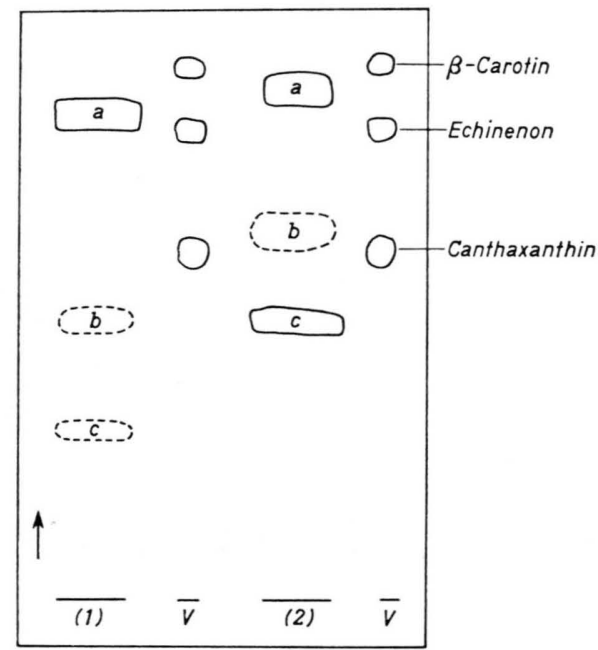

Abb. 2. Kopie eines Dünnschichtchromatogramms der nativen, in Aceton gelösten Gesamtpigment-Extrakte von Actinia equina aus der Adria (1) und aus der Nordsee (2).

Chromatographische Bedingungen: Schicht: Kieselgel-Alufolie „Merck“. Fließmittel: Benzin (Sdp. $100-140{ }^{\circ} \mathrm{C}$ ) - iso-Propanol-Chloroform $(90+10+70)$. Laufstrecke: $15 \mathrm{~cm}$; Kammersättigung; Zimmertemperatur.

Identifizierung der Einzelkomponenten: $\bigcirc$ : Hauptpigmente; : Nebenpigmente. (1). a: Actinioerythrin (violett gefärbt), ca. $80 \%$ der Gesamtpigmente. b u. c: violett gefärbt. (2). a u. $\mathrm{c}$ : Astaxanthinester (orange gefärbt), zusammen ca. $80 \%$ der Gesamtpigmente. b: Astaxanthinester (orange gefärbt). Gelegentlich treten bei (1) und (2) noch weitere Carotinoide in Spuren auf. Sie ändern jedoch nichts an der typischen Verteilung des Actinoerythrins und der Astaxanthinester. V: Vergleichssubstanzen in Aceton gelöst.

4 S. Hertzberg u. S. Liahen-Jensen, Acta chem. scand. 22, 1714 [1968].

5 E. Lederer, C. r. Soc. Biol. 113, 1391 [1933].

6 I. M. Heilbron, H. Jackson u. R. N. Jones, Biochem. J. 29, 1384 [1935].

7 M. De Nicola u. T. W. Goodwin, Pubbl. Staz. Zool. Napoli 25, 1 [1954]. 
ca. $200 \mathrm{mg}$ schwer; Adriatiere ca. $500 \mathrm{mg}$ schwer) veränderten bei gleichen Kultur- und Ernährungsbedingungen innerhalb eines Jahres ihre typische Pigmentgarnitur nicht. - Das Merkmal Vorhandensein von Actinoerythrin läßt sich daher zur chemotaxonomischen Unterscheidung der verschiedenen Actinia-equinaGruppen heranziehen. Bereits die Spektren nativer Gesamtextrakte von Tieren, die 14 Tage nicht gefüttert wurden, um eine Verfälschung der Ergebnisse durch Carotinoid-haltige unverdaute Nahrung zu vermeiden, zeigen eindeutige Differenzen (Abb. $1: \lambda$ max. in Ace-

8 Interessanterweise haben Hertzberg u. LiaAen-Jensen ${ }^{4}$ Actinioerythrin aus Actinien isoliert, die im Atlantik bei Bergen gesammelt worden waren. ton für Nordsee-Tiere: ca. $475 \mathrm{~nm}$ und für Adria-Tiere: ca. $503 \mathrm{~nm})$. Ein einfacher dünnschichtchromatographischer Test verdeutlicht diese Unterschiede noch (Abb. 2). - Untersuchungen mit weiteren ökologischen und geographischen Rassen von Actina equina, z. B. aus dem Schwarzen Meer, aber auch aus anderen Gebieten des Atlantiks ${ }^{8}$, und mit anderen Actinia-Arten werden zeigen, inwieweit die Zusammensetzung der Carotinoide neben anderen Merkmalen möglicherweise zur biochemischen Abgrenzung von Arten und Rassen herangezogen werden kann.

Fräulein A. KRÜGER (Würzburg) danken wir für ihre sorg. fältige Mitarbeit bei den Versuchen und der Deutschen Forschungsgemeinschaft für Sachbeihilfen.

\section{About the Fluorescence of Prodigiosin Isolated from Serratia Marcescens}

Dimiter P. Dimitrov

Central Laboratory of Biophysics, Bulgarian Academy of Sciences, Sofia 13, Bulgaria

(Z. Naturforsch. 25 b, 762-763 [1970]; eingegangen am 28. April 1970)

The effect of various substances and solvents on the colour change of prodigiosin has been discussed in a number of publications ${ }^{1-5}$. Up to now, however, no investigations are known to deal with the fluorescence spectrum of the pigment and its behaviour in different solvents. In our previous work ${ }^{6}$ it was found that the change of the spectrum in the visible range was due to the pigment molecule association in the form of a dimer. This process is achieved by increasing the substance concentration in various solvents. The same process is observed on the addition of substances with a high dielectric constant (glycerine, water) to a dissolved monomeric form. These interactions have the same result - the dimerization of the pigment molecules, yet the molecular mechanism varies with the different interactions. This is the subject of another investigation.

The pigment was isolated from a wild strain of Serratia Marcescens supplied by the Institute of Bacteriological Control in Sofia. The extraction was effected according to the HUBARD and RIMINGTON method ${ }^{4}$. A Perkin-Elmer-450 UV spectrophotometer with a fluorescence attachment was used for the fluorescence measurements. The fluorescence intensity was measured in comparison with the maximum intensity in petroleum ether at a concentration of $3 \mathrm{mg} / \mathrm{ml}$.

After the extraction the prodigiosin remains dissolved in petroleum ether, almost entirely in a monomeric

1 R. Williams, I. Green, and D. Rappoport, J. Bacteriol. 71, 115 [1956].

2 C. WEISS, J. cellular comparat. Physiol. 34, 467 [1949].

3 M. Burgova, E. Lovyagina, N. Flina, and G. Gol'denBERG, Primenenie Metodov Spektroskopii v Prom. Prodovol'stven. Tovarov i Sel'sk. Khoz., Leningr. Gos. Univ., 1955, p. 173. form, with an absorption maximum at $465 \mathrm{~m} \mu$ (Fig. 1, curve 1). Starting from this state which corresponds to a concentration of $0.06 \mathrm{mg} / \mathrm{ml}$, we gradually increase the concentration with the parallel dimerization of the pigment molecules. This process is characterized by the appearance of a new absorption spectrum maximum at $532 \mathrm{~m} \mu$ (Fig. 1, curve 2) and the change of colour from yellow to red.

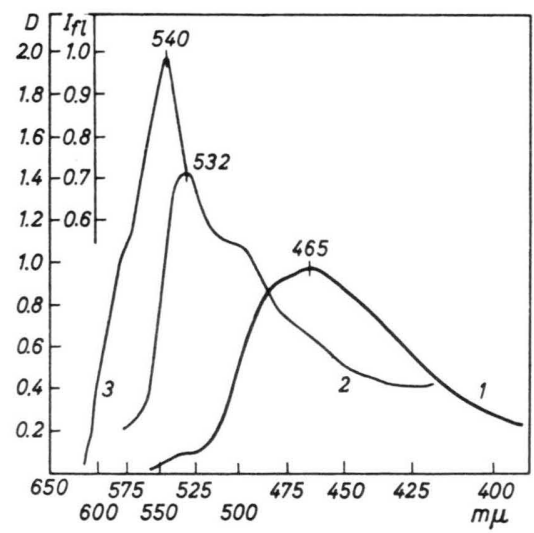

Fig. 1. Absorption and fluorescence spectrum in petroleum ether. Curve 1: Absorption spectrum of a monomeric form of prodigiosin (concentration $0.06 \mathrm{mg} / \mathrm{ml}$ ). Curve 2: Absorption spectrum of a dimeric form of prodigiosin (concentration $3 \mathrm{mg} / \mathrm{ml}$ ). Curve 3: Fluorescence spectrum (concentration $3 \mathrm{mg} / \mathrm{ml})$.

The investigation of the fluorescence spectrum in petroleum ether shows that the monomeric form of prodigiosin does not fluoresce. At concentrations marking the formation of the dimeric form (higher than $0.06 \mathrm{mg} / \mathrm{ml}$ ) a fluorescence of the pigment is ob-

4 R. Hubbard and C. Rimington, Biochem. J. 46, 220 [1950]. 16, 13 [1968].

5 E. Allen, Nature [London] 216, 929 [1967]. 